\title{
Urological Malpractice
}

Dan Arsenie Spinu ${ }^{1,2}$, Ioana Oprea ${ }^{3}$, Oana Bodean ${ }^{4}$, Bogdan Socea $^{5}$, Camelia Diaconu ${ }^{6}$, Dan Mischianu ${ }^{1,2}$, Dragos Marcu ${ }^{1,2}$, Ovidiu Gabriel Bratu ${ }^{1,2}$

\begin{abstract}
Malpractice is a relatively new term in terms of litigation. Prior to the early $18^{\text {th }}$ century, medical malpractice lawsuits were mainly limited to cases that resulted in severe injury and death. At the beginning of the $19^{\text {th }}$ century, things started to change for the medical practitioners, unfortunately not in a good way. What seemed to have started in the USA, spread like fire throughout the Western Europe. This state of affair prompted physicians to practice the socalled "defensive medicine". It is well known that surgery in general and urologic surgery in particular is associated with iatrogenic injury and high-risk procedures that do not always have a positive outcome. Moreover, office urology seems to also imply a high degree of litigation risk. The aim of this paper was to determine the fields in Urology that are most prone to litigation and malpractice lawsuits.
\end{abstract}

Keywords: urology, litigation, malpractice

\section{Rezumat}

Malpraxisul este un termen relativ nou în ceea ce privește litigiile. Anterior secolului 18, procesele de malpraxis medical se limitau în principiu la cazuri care presupuneau vătămări grave și deces. În prima parte a secolului 19, lucrurile au început să se schimbe pentru medici, însă, din păcate, nu în bine. Ceea ce se pare că a început în SUA s-a extins ca un foc în toată Europa de Vest. Această stare de fapt a determinat doctorii să practice așa-zisa medicină defensivă. Este bine cunoscut faptul că chirurgia, în general, și chirurgia urologică, în special, este asociată cu leziunile iatrogene și cu operațiile cu risc mare care nu au întotdeauna un rezultat pozitiv. În plus, se pare că urologia de birou presupune de asemenea un grad înalt al riscului de litigiu. Scopul acestei lucrări a fost să stabilească domeniile din urologie care sunt cele mai predispuse litigiului și proceselor de malpraxis.

Cuvinte cheie: urologie, litigiu, malpraxis

Nowadays, doctors face a challenging medico-legal environment. This is also the case of urologists with many legal claims against them. The fact that urology is a surgical specialty is not encouraging, surgical specialties being situated on top of the chain.

One of the most important problems is the lack of information from the specialized editorials. This kind of data is hard to find especially since it is often regarded as confidential information.

An estimated amount of 10 million dollars is spent annually in the US on malpractice lawsuits ${ }^{1}$. These figures are of a particular concern to surgeons as postoperative complications have proved to be the most costly type of error and may constitute up to $39 \%$ of

\footnotetext{
${ }^{1}$ Clinic of Urology, „Dr. Carol Davila” Central Military Emergency University Hospital, Bucharest, Romania

${ }^{2} 3^{\text {rd }}$ Clinical Department, "Carol Davila" University of Medicine and Pharmacy, Bucharest, Romania

${ }^{3}$ Department of Intensive Care Unit, „Dr. Carol Davila” Central Military Emergency University Hospital, Bucharest, Romania

${ }^{4}$ Obstetrics and Gynecology Department, Emergency University Hospital, Bucharest

${ }^{5}$ Surgery Department, St. Pantelimon Emergency Hospital, Bucharest

${ }^{6}$ Department of Internal Medicine, Floreasca Emergency Hospital, Bucharest
}

\section{Corresponding author.}

Ovidiu Bratu, Clinic of Urology, „Dr. Carol Davila” Central Military Emergency University Hospital, Bucharest, Romania.

E-mail: ovi78doc@yahoo.com 
the costs for medical errors ${ }^{2}$. Private urologic services are not spared of litigation too.

The researchers noted that urology ranked the eighth, out of 25 specialties, for a number of malpractice claims. They also added that during an average career, an urologist would be sued at least twice.

The most concerning aspect is that claims are continually increasing. The causes are multiple: unfounded expectations, lower standards in some hospitals, and the most important one, the mirage of financial rewards, which is increasing year after year. Moreover, cases in which the law firm practically "fishes" the client in hope of a financial reward and reputation should not be omitted.

The reasons are different starting with the incorrect installation of the urinary catheter and ending with various complications post radical prostatectomy.

As such, in 2016, Mohannad et al. evaluated the urological legal complaints related to urinary catheters installations in patients over 50 years old. They identified 29 cases in which the great majority of lawsuits were won by the urologist and not by the patient. Pain was the most common type of damage claimed by the patients (28\%), followed by UTI (24\%). Nineteen cases (66\%) favored defendants, while 10 cases (34\%) favored the plaintiffs, of which $2(7 \%)$ were settled out of the court ${ }^{3}$.

Penile surgery is situated in one of the top positions in urological malpractice with reconstructive surgery holding the first position. Penile prosthesis procedure implies high risks for the surgeon, therefore some of them started to avoid using it because of possible malpractice. Although the procedure is successful most of the times, a potential failure cannot be ruled out. Using the Westlaw legal database, Chason et al. identified cases involving penile prostheses that occurred between January 1990 and December 2013. Forty cases were analyzed. Their conclusion was that penile reconstructive surgery is not so much implied in malpractice lawsuits and that the focus on communication and on obtaining an informed consent could greatly reduce malpractice risk for urological procedures ${ }^{4}$. They considered that in order to avoid malpractice, it is very important for a professional to take into consideration breaches of duty, managing patient expectations, skill level and device selection.

Even more, in a paper from 2014, Sunaryo Peter et al. evaluated 40 patients with penile prosthesis. Twenty three cases $(57.5 \%)$ were found in favor of the defendant, while 17 cases (42.5\%) led to indemnity payment to the plaintiff, including two cases $(5.0 \%)$ that were settled out of court and 15 (37.5\%) favoring the plaintiff in front of a jury. The informed consent was an issue in 13 filings (31.7\%), and postoperative infection was met in 13 cases $(31.7 \%)^{5}$.

Kaplan GW made an interesting and novel approach. He anonymously investigated urologists in the USA in terms of malpractice lawsuits. The conclusion of this study was astonishing: „Most urologists can expect to be sued at least twice in their professional careers".

Other authors favored his inverse approach starting from the information provided by malpractice insurance companies. Thus, Coogan CL and Benson JS analyzed data obtained from 20 insurance companies for a period of 22 years and found that urology is ranked $12^{\text {th }}$ of 28 . The most common errors are improper performance, diagnostic errors, and failure to monitor cases. Diseases that have occurred most often due to these errors are within the neoplastic area (kidney, prostate, and testis) ${ }^{7}$.

One of pathologies frequently involved in litigations is testicular torsion. In this case, a notable difference can be observed between various databases and the practical access to information itself. Thus, a paper confirmed 52 cases in three years while in another paper 53 cases were found in 30 years...

It is quite natural, considering that it is a pathology rather difficult to investigate, the clinical examination having a great weight in the process. An urologist loses at the state level because of the delayed time to the operating room! Conclusions of both works consist in the idea that the urologist rarely loses while an emergency doctor is prone to lose more ${ }^{8,9}$.

Office urology is also faced with a decrease in activity, change in the working state or refers the patient to a colleague. In these situations, a shortage of medical specialists in several surgical fields may occur. UK is one of the countries in which the local population prefers to focus on specialties less dangerous legally ${ }^{10}$.

Moreover, the latest works rate urology the eight in the ranking, the authors summing up a period of 14 years. It was estimated that by the age of 65 years, $75 \%$ of the physicians in the low risk specialties had faced a malpractice claim, as compared with $99 \%$ of the physicians in the high-risk specialties ${ }^{11}$.

Badger et al. analyzed a total of 75 misdiagnosis claims over a period of 20 years. They were divided into 58 urological misdiagnoses and 17 non-urological misdiagnoses. The liability of the urologist resulted not only 
from urology cases but also from non-urological situations ${ }^{12}$.

One of the most comprehensive papers in literature, which addressed urologic medico-legal matters, belongs to Osman et al. who analyzed 14 years of successful urological litigations in the UK national health system. Besides other procedures and anatomical zones in the pelvic area, vasectomy and reconstructive surgery seem to hold the first lines ${ }^{13}$. Although the numbers may look small, it is merely an illusion given by the fact that the overall number of reconstructive procedures does not exceed fifteen.

A more specific approach was made by Duty B et al. who analyzed in their work litigation in endourology in the state of New York. 25 closed claims on a 5-year period were found, 16 of them being women. Endourology and urological oncology generate the greatest number of lawsuits against urologists. Surprisingly, almost all of them were urolithiasis related ${ }^{14-19}$.

Last but not least, there are two very important studies: the first led by Kahan SE studied 259 medical malpractice claims against urologists consecutively closed from 1995 to 1999, the latter led by Perrotti M found 469 urology malpractice claims that were closed with indemnity payment. The first one found that en- dourology was the most incriminated, the second one deemed oncourology as the most frequent claim ${ }^{20-29}$.

\section{CONCLUSIONS}

The current medical malpractice crisis has consumed the urologists as well. The law firms target multiple causes starting from improper performance, diagnostic errors, failure to monitor cases, and ending with endourology and uroncology. More and more patients are affected by the prize mirage. Nevertheless, there are also small procedures such as vasectomy that have a great percentage. Continued analysis and education on medical litigation in urology can help increase the awareness and possibly improve care for patients in the future.

\section{Compliance with ethics requirements:}

The authors declare no conflict of interest regarding this article.

The authors declare that all the procedures and experiments of this study respect the ethical standards in the Helsinki Declaration of 1975, as revised in 2008(5), as well as the national law. Informed consent was obtained from all the patients included in the study.

\section{References}

1. Kohn LT, Corrigan JM and Donaldson MS: To Erris Human: Building a Safer Health System Washington, DC: The National Academies Press 2000.

2. Thomas EJ, Studdert DM, Newhouse JP et al: Costs of medical injuries in Utah and Colorado. Inquiry 1999; 36: 255.

3. Mohannad A. Awad, E. Charles Osterberg1, Helena Chang, Thomas W. Gaither, Amjad Alwaal3, Ryan Fox4, Benjamin N. BreyerUrethral catheters and medical malpractice: a legal database review from 1965 to 2015 - Translational Andrology and Urology, Vol 5, No 5 October 2016.

4. Chason J, Sausville J, and Kramer AC. Penile prosthesis implantation compares favorably in malpractice outcomes to other common urological procedures: Findings from a malpractice insurance database. J Sex Med 2009;6:2111-2114.

5. Sunaryo PL, Colaco M, and Terlecki R. Penile prostheses and the litigious patient: A legal database review. J Sex Med 2014;11: 2589-2594.

6. Kaplan GW Malpractice risks for urologists. Urology. 1998 Feb; 51(2):183-5

7. Benson JS, Coogan CL Urological malpractice: analysis of indemnity and claim data from 1985 to 2007, J Urol. 2010 Sep;184(3):1086-90; quiz 1235. doi: 10.1016/j.juro.2010.05.034. Epub 2010 Jul 21

8. Thomas W. Gaither and Hillary L. Copp - State appellant cases for testicular torsion: Case review from 1985 to 2015, Pediatr

Urol. 2016 October; 12(5): 291.e1-291.e5. doi:10.1016/j.jpurol. 2016.03.008.

9. Marc Colaco, Matthew Heavner, Peter Sunaryo, Ryan Terlecki, Malpractice Litigation and Testicular Torsion: A Legal Database Review, J Emerg Med. 2015 Dec;49(6):849-54. doi: 10.1016/j. jemermed.2015.06.052. Epub 2015 Sep 26.

10. Sobel DL, Loughlin KR, Coogan CL. Medical malpractice liability in clinical urology: a survey of practicing urologists. J Urol. 2006 May; 175(5):1847-51

11. Anupam B. Jena., Seth Seabury., Darius Lakdawalla., and Amitabh Chandra, Malpractice Risk According to Physician Specialty, $n$ engl $j$ med 365;7 nejm.org august 18, 2011

12. Badger WJ, Moran ME, Abraham C, Yarlagadda B, Perrotti M., Missed diagnoses by urologists resulting in malpractice payment. J Urol. 2007 Dec;178(6):2537-9. Epub 2007 Oct. 13 Osman NI, Collins GN. Urological litigation in the UK National Health Service (NHS): an analysis of 14 years of successful claims. B JU Int $2011 ; 108: 162-5$.

14. Duty B, Okhunov Z, Okeke Z, Smith A., Medical malpractice in endourology: analysis of closed cases from the State of New York., J Urol. 2012 Feb;187(2):528-32. doi: 10.1016/j.juro.2011. 10.045. Epub 2011 Dec 15.

15. Perrotti M, Badger W, Prader S, Moran ME, Medical malpractice in urology, 1985 to 2004: 469 consecutive cases closed with indemnity payment., J Urol. 2006 Nov; 176(5):2154-7; discussion 2157. 
16. Kahan SE, Goldman HB, Marengo S, Resnick MI, Urological medical malpractice, J Urol. 2001 May; 165(5):1638-42.

17. Value of ultrasound elastography in the diagnosis of native kidney fibrosis - Peride I, Rădulescu D, Niculae A, Ene V, Bratu OG, Checherită IA. - Med Ultrason. 2016 Sep;18(3):362-9. doi: 10.11152/mu.2013.2066.183

18. Synthesis and Characterization of Novel $\mathrm{Cu}(\mathrm{II}), \mathrm{Pd}(\mathrm{II})$ and $\mathrm{Pt}(\mathrm{II})$ Complexes with 8-Ethyl-2-hydroxytricyclo(7.3.1.0(2,7))tridecan-13-one-thiosemicarbazone: Antimicrobial and in Vitro Antiproliferative Activity - Pahontu E, Paraschivescu C, llies DC, Poirier D, Oprean C, Păunescu V, Gulea A, Roșu T, Bratu O. - Molecules. 2016 May 21;21(5). pii: E674. doi: 10.3390/molecules21050674.

19. Calcific uremic arteriolopathy in hemodialyzed patients. - Checheriță IA, Smarandache D, Rădulescu D, Peride I, Bratu O, Ciocâlteu A, Sebe I, Lascăr I. - Chirurgia (Bucur). 2013 Sep-Oct; 108(5):736-40.

20. Difficulties in diagnosis and surgical treatment of a giant retroperitoneal lipoma. - Constantinoiu S, Bârlă R, Iosif C, Cociu L, Gîndea C, Hoară P, Bratu O, Ruşitoru L. - Chirurgia (Bucur). 2009 May-Jun;104(3):363-7.

21. Renal artery bilateral arteriosclerosis cause of resistant hypertension in hemodialysed patients. - Niculae A, Peride I, Marinescu-Paninopol A, Vrabie CD, Ginghină O, Jecan CR, Bratu OG. - Rom J Morphol Embryol. 2016;57(2):591-4.

22. Vitamin $\mathrm{K}$ influence on cardiovascular mortality in chronic hemodialysed patients - Rădulescu D, Balcangiu Stroescu A, Pricop C, Geavlete B, Negrei C, Bratu O, Ginghină O, Văcăroiu I - Revista de Chimie, vol. 68, nr. 1, 2017
23. Mullerianosis of the urinary bladder: a rare case report and review of the literature - Stanimir M, Chiutu LC, Wese S, Milulescu A, Nemes RN, Bratu O - Rom J Morphol Embryol. 2016;57(2 Suppl):849-852.

24. Nephrotic syndrome secondary to amyloidosis in a patient with monoclonal gammopathy with renal significance (MGRS) - Andrei Niculae, Ileana Peride, Vlad Vinereanu, Daniela Rădulescu, Ovidiu Gabriel Bratu, Bogdan Florin Geavlete, Ionel Alexandru Checheriță - Rom J Morphol Embryol. 2017;58(3).

25. Superior vena cava syndrome - Paraschiv B, Dediu G, lancu A, Bratu O, Diaconu C - Archives of the Balkan Medical Union, vol. 52, No. 1, 2017

26. Spiegel hernia - Case presentation - Bogdan Socea, Alexandru Smaranda, Anca Nica, Ovidiu Bratu, Camelia Diaconu, Laura Socea, Dan Dumitrescu, Mihai Dimitriu, Alexandru Carap, Vlad Constantin - Archives of the Balkan Medical Union, Vol. 53, Iss. 1,2018

27. The lung effects of illicit drugs - Crista Laslo, Beatrice Ioan Ovidiu Bratu, Bogdan Socea, Camelia Diaconu - Archives of the Balkan Medical Union, Vol. 53, Iss. 1, 2018

28. Pulmonary involvement in rheumatoid arthritis-another face of the coin - Georgiana Iftimie, Ovidiu Bratu, Bogdan Socea, Mihaela Iancu, Ana Maria Stanescu, Giorgiana Dediu, Bianca Paraschiv, Camelia Diaconu - Archives of the Balkan Medical Union, Vol. 53, Iss. 1, 2018

29. Liver abnormalities in patients with heart failure - Teodora Draghici, Lucian Negreanu, Ovidiu Bratu, Radu Tincu, Bogdan Socea, Mihaela Iancu, Ana Maria Stanescu, Camelia Diaconu Archives of the Balkan Medical Union, Vol. 53, Iss. 1, 2018. 